\title{
Renal Urea Clearance in Normal and Adrenalectomized Rats after Exercise
}

\author{
L. Litvinova, A. Viru, and T. Smirnova \\ Department of Sports Physiology and \\ Research Laboratory of Hormonal Regulation of Muscular Activity, Tartu State \\ University, 18 Ylikooli, Tartu 202400, Estonian S.S.R., U.S.S.R.
}

\begin{abstract}
In groups of male Wistar rats, blood level, urinary excretion of urea, and renal urea clearance were determined in resting conditions or during 48-60 h after swimming for $30 \mathrm{~min}$ with an additional load of $10 \%$ of body weight as well as after swimming for 3 or $10 \mathrm{~h}$ without additional load. Both types of swimming exercise caused a significant increase in the blood level, urinary excretion, and renal clearance of urea. After 10-h swimming, the increase of renal urea clearance was observed only from the second period $(0-12 \mathrm{~h})$ of urine collection. In this type of exercise, an elevation of blood level of corticosterone was obtained after 6-h restitution. The increased urinary excretion and renal urea clearance persisted for a longer time than was necessary for the normalization of the blood level. A significant rise in blood urea level and a drop in renal urea clearance occurred after adrenalectomy. In adrenalectomized rats, increased urea excretion and renal clearance were observed $12-24 \mathrm{~h}$ after 3 -h swimming, but the level of renal clearance obtained in sedentary normal rats was not achieved. The blood level of urea did not increase. This suggested that the glucocorticoids play a role both in urea formation during exercise and in its elevated renal clearance after exercise.
\end{abstract}

Key words: urea in blood and urine, urea renal clearance rate, corticosterone, adrenalectomy, exercise.

During heavy exercise, enhancement of protein catabolism (LEMON and NAGLE, 1981; Dohm et al., 1985a; Goodman and Ruderman, 1987; Viru, 1987) and deamination of purine nucleotides (LOWENSTEIN, 1972) are observed in association with an increased rate of urea production leading to elevated urea levels in the blood (Rogozkin, 1959; Chailley-Bert et al., 1961; Lenkova et al., 1973; BuHL et al., 1974; Refsum and Strömme, 1974; Haralambie and Berg, 1976; Lorenz and Gerber, 1979), tissues (RogozKIN, 1959; LeNKova et al., 1973), urine (Chailley-Bert et al., 1961; Refsum and Strömme, 1974; Lemon and Mullin, 1980;

Received for publication January 16, 1989 
Dohm et al., 1982), and sweat (Refsum and Strömme, 1974; Lemon and Mullin, 1980). It is suggested that the increase in blood urea level is promoted by retarded renal excretion of urea due to an altered blood supply to the kidneys (LORENZ and Gerber, 1979; Goodman and Ruderman, 1987). After exercise, a high level of urea in blood is maintained for a long time (REFSUm and STRÖMmE, 1974; BuHL et al., 1978; Doнm et al., 1982) together with retarded excretion during the daytime and augmented excretion at night (ZERBES et al., 1983). As our aim was to elucidate the role of renal function in urea dynamics, we studied the effect of swimming of various duration on the renal clearance of urea in rats.

During various types of exercise, the adrenocortical activity exhibits various changes depending on the intensity and duration of muscular activity (VIRU, 1985). Since glucocorticoids have a strong action on the urea production (ENGEL, 1951; SCHIMKe, 1963) and renal excretion (BELlamy and LeONARD, 1964), the changes in normal rats were compared with those in adrenalectomized animals.

\section{METHODS}

Male Wistar rats (body weight, $210 \pm 8.5 \mathrm{~g}$ ) were maintained on a standardized laboratory diet, containing $12-15 \%$ of protein, $26-30 \%$ of carbohydrate, and $8-10 \%$ of fat. Drinking water was allowed ad libitum. Animals were placed in individual metabolic cages, and excreted urine was collected during days before and after swimming every $12-\mathrm{h}$ period. At the beginning and end of every $12-\mathrm{h}$ period, blood samples were taken from the tail. Urine and blood urea concentrations were determined with the aid of the Bio-la-test kit of Lachema (ČSSR).

Normal rats were divided into a control group $(n=8)$ and three other groups that had to swim in the water, which was $32 \pm 1^{\circ} \mathrm{C}$. Group 1 swam for $30 \mathrm{~min}$ with an additional load of $10 \%$ of body weight, attached on the tail $(n=9)$; group 2 swam for $3 \mathrm{~h}(n=10)$ and group 3 for $10 \mathrm{~h}(n=13)$, both without any additional load. The whole group of rats swam together in a water tank to maintain active movements during the exercise. The average water surface per rat was $80 \mathrm{~cm}^{2}$.

The renal clearance of urea was calculated by the following formula:

$$
\begin{aligned}
& \text { Renal urea clearance }\left(\mathrm{ml} \cdot \mathrm{ml}^{-1}\right) \\
& =\frac{\text { urea concentration in urine }\left(\mathrm{mg} \cdot 100 \mathrm{ml}^{-1}\right)}{\text { mean urea concentration in blood }\left(\mathrm{mg} \cdot 100 \mathrm{ml}^{-1}\right)} \times \text { urine volume }\left(\mathrm{ml} \cdot \mathrm{min}^{-1}\right) \text {. }
\end{aligned}
$$

The mean urea concentration in blood represents the mean value of urea concentration at the start and end of the period of urine collection.

An additional experiment was performed on the male Wistar rats to observe the changes in blood corticosterone level during swimming of various durations (30 and $90 \mathrm{~min}, 4,8,10,12$, and $16 \mathrm{~h}$ ). The rats were decapitated and blood was collected immediately after swimming. After 10 -h swimming, the groups of rats were decapitated $1,2,6,24$, or $48 \mathrm{~h}$ after the end of swimming. The blood plasma 
level of corticosterone was determined fluorometrically (STEWARD et al., 1961) after thin-layer chromatography (KǒRGE et al., 1974).

Fourteen rats were adrenalectomized 8 days prior to the experiment and held on $1 \%$ of $\mathrm{NaCl}$ in drinking water. Six of them had to swim for $3 \mathrm{~h}$ without an additional load. In this series an additional control group of 12 sham-operated rats was used.

\section{RESULTS}

All the three types of swimming exercise cause a significant increase in blood urea level and urinary urea excretion in normal rats. The blood urea concentration returned to the normal level within $24 \mathrm{~h}$ after 30-min swimming (Fig. 1) or 3-h swimming (Fig. 2). Following swimming for $10 \mathrm{~h}$, the urea level in blood normalized within $60 \mathrm{~h}$ of postexercise recovery (Fig. 3). In spite of the gradual reduction of blood urea concentration, the urea excretion rate remained elevated in all groups loaded with swimming exercise.

Renal clearance of urea was augmented after all types of swimming exercise (Table 1). In the case of 30-min swimming exercise, the augmentation was observed only during the first $12-\mathrm{h}$ postexercise period. Following the 3 -h swimming exercise, the elevated renal clearance of urea persisted for $36 \mathrm{~h}$ after the exercise. In the case of 10-h swimming, the urea clearance was diminished in the period of the postexercise

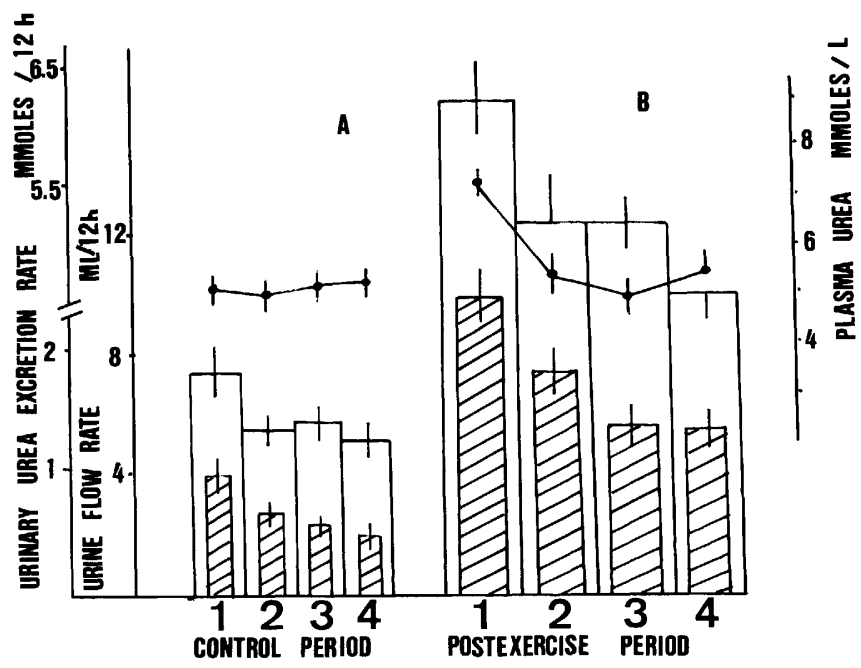

Fig. 1. Urea level of blood plasma (solid line), urinary urea excretion rate (white columns), and urine flow rate (striated columns) in rats after swimming exercise for $30 \mathrm{~min}$. In this group, an additional weight of $10 \%$ of body weight was loaded during exercise. A: sedentary control. B: after swimming exercise. Periods 1: 0-12 h; 2: $12-24 \mathrm{~h} ; 3: 24-36 \mathrm{~h} ; 4: 36-48 \mathrm{~h}$. Each point represents the mean \pm S.E.M. of the group. 


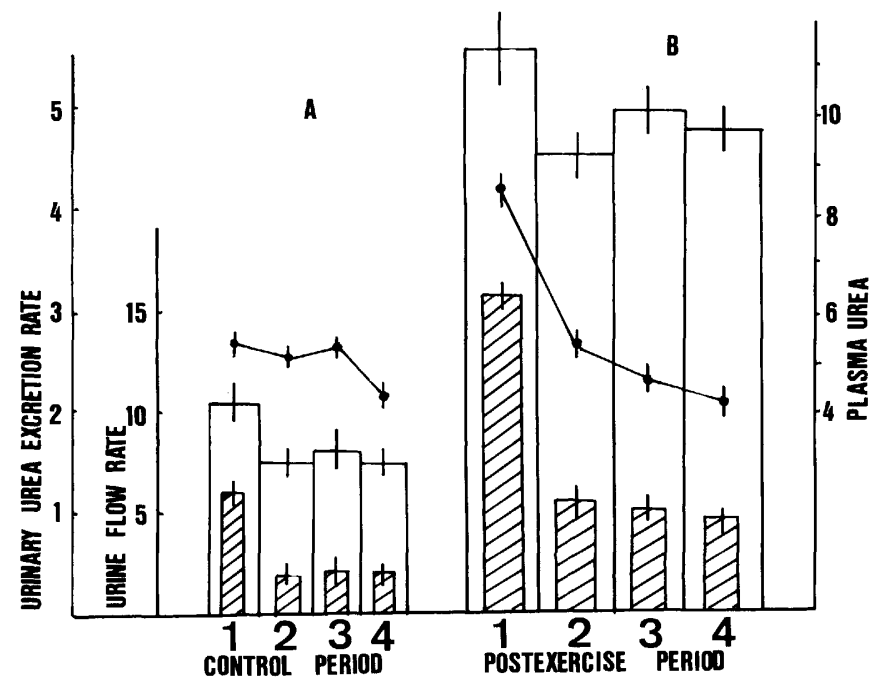

Fig. 2. Urea level of blood plasma, urinary excretion rate of urea, and urine flow rate in rats after swimming exercise for $3 \mathrm{~h}$. In this group, no additional weight was loaded during exercise. Explanations for lines, and columns are the same as in Fig. 1 legend.

recovery. Thereafter it increased up to the highest level in the third period $(24-36 \mathrm{~h})$. The clearance returned to the normal level in the fifth period (48-60 h).

A good accordance was obtained between changes in urea excretion, renal clearance, and urine flow rate during postexercise recovery phases.

Determination of plasma corticosterone levels after swimming exercise of various durations showed that even 30 -min swimming caused a significant increase in the hormone concentration (Table 2). High corticosterone level was observed in the animals loaded with swimming exercise for up to $8 \mathrm{~h}$. On the other hand, the animals that swam for 12 and $16 \mathrm{~h}$ did not show any increase in corticosterone concentration as compared with the control group. After 10-h swimming, an increase in the blood corticosterone concentration was found after a 6-h recovery period.

A significant rise in the blood urea level and a drop in the renal clearance rate of urea were induced by adrenalectomy (Table 3). In adrenalectomized rats, 3-h swimming did not cause any elevation of blood urea level. The urea excretion and renal clearance was increased $12-24 \mathrm{~h}$ after 3 -h swimming, but remained below the level of sedentary control rats.

\section{DISCUSSION}

In accordance with the results of previous studies (REFSUM and STRÖMME, 1974; BuHL et al., 1978; Dонм et al., 1982), the obtained results show that the high level of urea in blood and urine is maintained for a long time after prolonged exercises. 


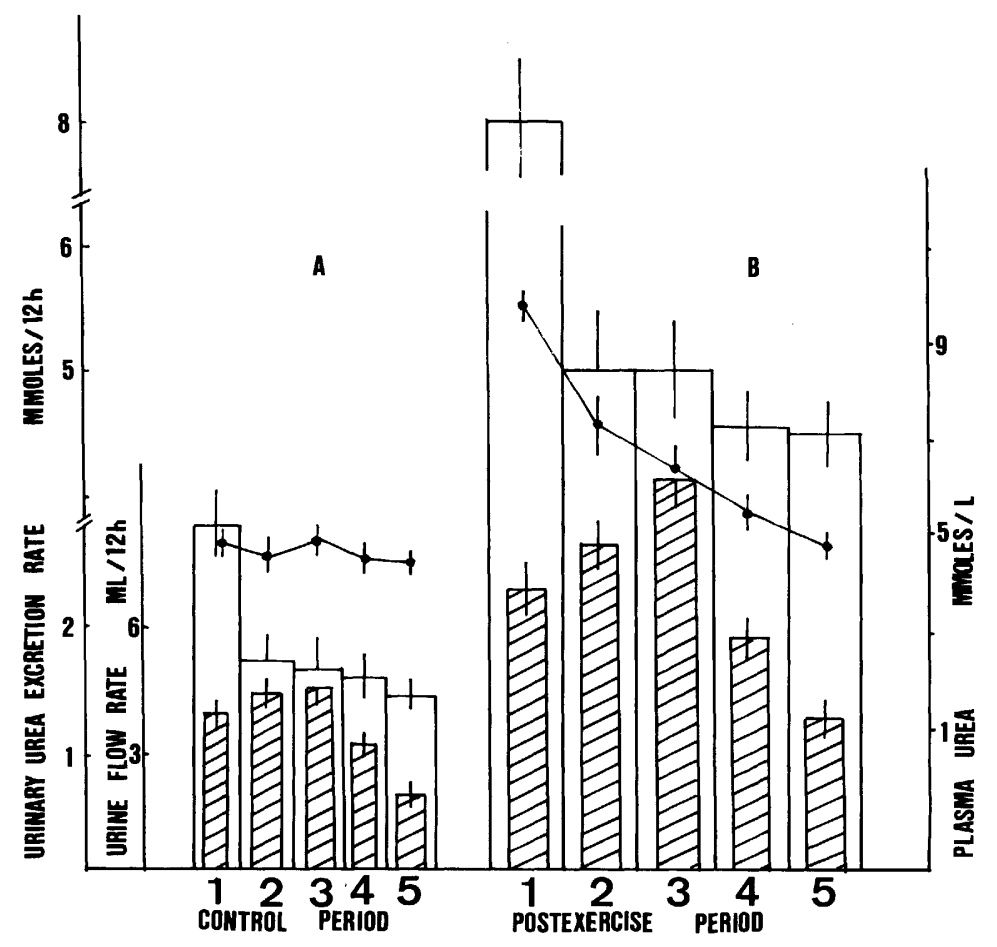

Fig. 3. Urea level of blood plasma, urinary excretion rate of urea, and urine flow rate in rats after swimming exercise for $10 \mathrm{~h}$. In this group no additional weight was loaded during exercise. Explanations for lines and columns are the same as in Fig. 1 legend.

According to our results, the increased urinary excretion of urea persists even longer than is necessary for the normalization of the blood level. In parallel with the increased excretion rate, the renal clearance was elevated. Hence, there is not any retardation of urea elimination at the kidney level, at least in rats, after exercise. On the contrary, the conditions for urea elimination improved after exercise. A good accordance between urine flow rate, urea excretion, and renal clearance suggests that the increase of the urine flow rate is important factor of urea washout after exercise.

A retarded urea elimination might take place during the exercise and a short time after it due to the reduced blood supply to kidney (RoweLL, 1974). The period of retarded urea elimination may be prolonged and a postexercise retardation may occur in the case of vigorous exercise. In accordance with this suggestion, the increased urea excretion and elevated renal clearance rates. were observed only from the 12 th hour on after 10 -h swimming.

Results of various studies indicate that the postexercise recovery period is characterized not only by augmentation of protein synthesis but also by an increased 


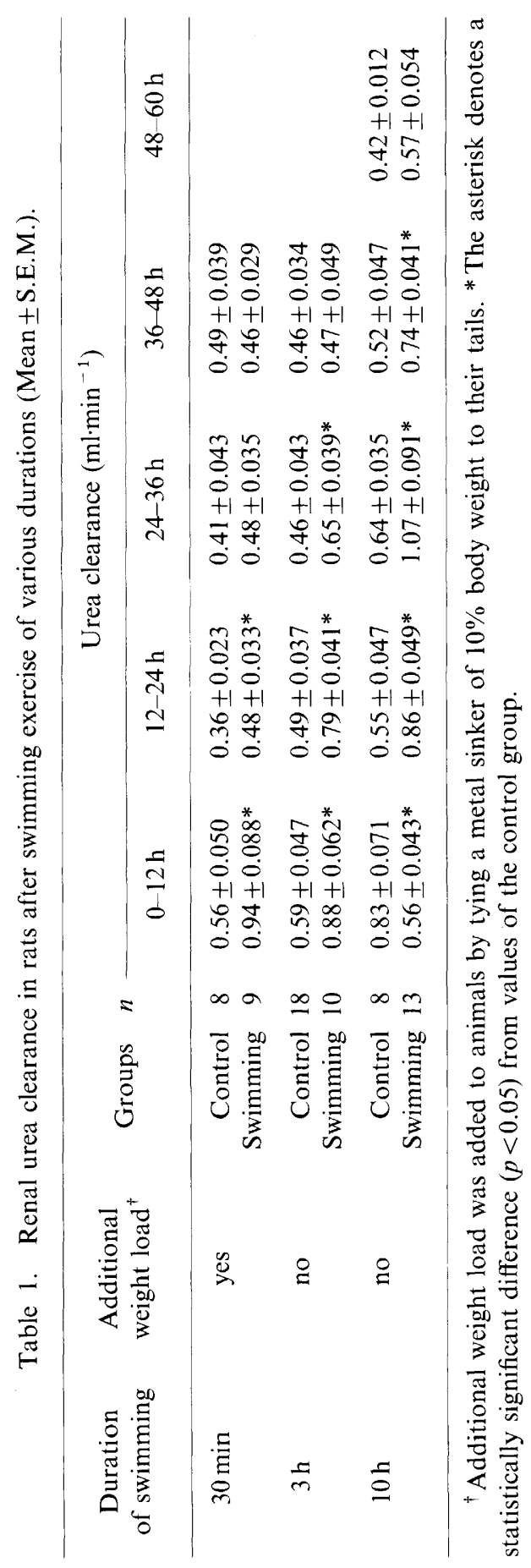

Japanese Journal of Physiology 


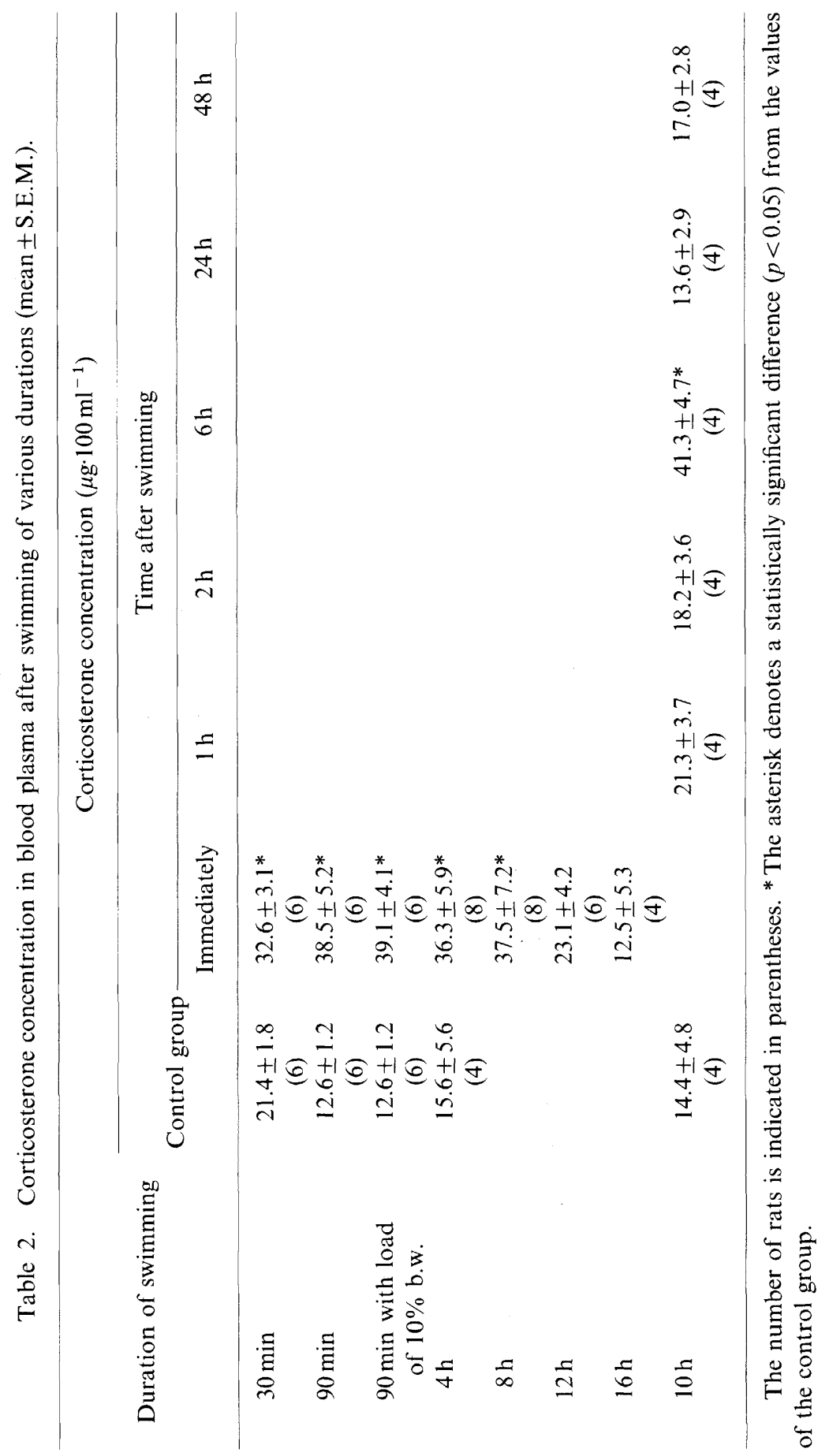

Vol. 39, No. 5, 1989 
Table 3. Urea level of blood, urinary excretion rate of urea, and renal urea clearance in adrenalectomized rats (mean \pm S.E.M.).

\begin{tabular}{|c|c|c|c|c|c|}
\hline \multirow{2}{*}{ Groups } & \multirow{2}{*}{$n$} & \multicolumn{4}{|c|}{ Periods after swimming } \\
\hline & & $0-12 \mathrm{~h}$ & $12-24 \mathrm{~h}$ & $24-36 \mathrm{~h}$ & $36-48 \mathrm{~h}$ \\
\hline & & \multicolumn{4}{|c|}{ Urea concentration in blood $\left(\mathrm{mM} \cdot \mathrm{l}^{-1}\right)$} \\
\hline Control & 12 & $3.53 \pm 0.48$ & $3.70 \pm 0.41$ & $3.83 \pm 0.39$ & $3.91 \pm 0.37$ \\
\hline Adrenalectomy & 8 & $7.20 \pm 0.47^{*}$ & $6.86 \pm 0.48^{*}$ & $6.80 \pm 0.32 *$ & $6.75 \pm 0.31^{*}$ \\
\hline \multicolumn{6}{|l|}{ Adrenalecotomy } \\
\hline + swimming & 6 & $7.30 \pm 0.45^{*}$ & $6.71 \pm 0.33^{*}$ & $3.90 \pm 0.31^{* *}$ & $5.38 \pm 0.33^{*}$ \\
\hline \multicolumn{6}{|c|}{ Urinary excretion rate of urea $\left(\mathrm{mmol} \cdot 12 \mathrm{~h}^{-1}\right)$} \\
\hline Control & 12 & $1.90 \pm 0.15$ & $1.95 \pm 0.16$ & $1.92 \pm 0.15$ & $1.90 \pm 0.15$ \\
\hline Adrenalectomy & 8 & $1.60 \pm 0.35$ & $1.83 \pm 0.19$ & $1.66 \pm 0.36$ & $1.76 \pm 0.06$ \\
\hline \multicolumn{6}{|l|}{ Addrenalectomy } \\
\hline+ swimming & 6 & $2.00 \pm 0.28$ & $2.66 \pm 0.27 * *$ & $1.39 \pm 0.16^{*}$ & $1.55 \pm 0.09^{*}$ \\
\hline \multicolumn{6}{|c|}{ Renal urea clearance $\left(\mathrm{ml} \cdot \mathrm{min}^{-1}\right)$} \\
\hline Control & 12 & $0.74 \pm 0.073$ & $0.73 \pm 0.069$ & $0.75 \pm 0.071$ & $0.74 \pm 0.057$ \\
\hline Adrenalectomy & 8 & $0.31 \pm 0.050^{*}$ & $0.37 \pm 0.052^{*}$ & $0.34 \pm 0.096^{*}$ & $0.36 \pm 0.062^{*}$ \\
\hline Adrenalectomy & & & & & \\
\hline + swimming & 6 & $0.38 \pm 0.057^{*}$ & $0.55 \pm 0.039^{* *}$ & $0.50 \pm 0.052^{*}$ & $0.40 \pm 0.092^{*}$ \\
\hline
\end{tabular}

* The asterisk denotes a statistically significant difference $(p<0.05)$ from the values of control group. ${ }^{* *}$ Two asterisks denote statistically significant difference $(p<0.05)$ between groups of sedentary and exercised adrenalectomized rats.

rate of protein degradation (MILLWARD et al., 1982; VIRU, 1987). The increased protein turonover contributes to the renewal of the molecular content of muscle proteins to eliminate the physiologically exhausted structure elements and to ensure an improvement of the function. The postexercise increase in muscle protein turnover is also reflected in the increase 3 methylhistidine excretion rate (DOHM et al., 1982, 1985b; KASPEREK and SNIDER, 1985; VIRU et al., 1985) and in the elevated 3-methylhistidine level in the blood (DoHM et al., 1985b) and the skeletal muscle tissue (VIRU et al., 1985) during the postexercise recovery period. The elevated protein degradation may be accompanied with additional urea production during the recovery period after exercise. The activity of hepatic arginase, an important enzyme in urea biosynthesis, remains elevated for many hours after exercise (YAKOVLEV, 1979). In our experiments, a secondary increase in the blood urea elevel was not observed during postexercise recovery. However, the enhanced excretion of urea in combination with augmented renal clearance persisted during a prolonged period after exercise. If the production and clearance were equal, the increased production might lead to an elevated urinary excretion without any increase in the blood level.

The increased adrenocotrical activity during exercise (VIRU, 1985) is a plausible factor of enhanced protein catabolism that is associated with augmented urea 
production. Glucocorticoids may be one of a number of factors responsible for the increased renal urea clearance also during the recovery period. According to classic knowledge, the adrenalectomy suppresses the urinary excretion of nitrogen (INGLE, 1949). The administration of corticotropin or glucocorticoids increases nitrogen excretion (INGLE, 1949), as well as urea excretion (Bellamy and LeONARD, 1964). The results of our study indicate that in adrenalectomized rats the decrease of renal urea clearance is associated with an increase of its concentration in blood, indicating a defect on the kidney level. Muscular activity did not increase the urea concentration in the blood of this group of animals. This fact agrees with the role of glucocorticoids in urea production (ENGEL, 1951; Schimke, 1963). However, muscular activity promoted an improvement of renal excretion of urea from the 12 th to the 24 th after exercise in adrenalectomized rats. This change was not sufficient to reach the levels of normal sedentary rats and the obtained rates of excretion and renal clearance were far below the rates in normal rats after exercise.

Intensive exercise increases the blood glucocorticoid level not only during exercise, but also during the recovery period (VIRU, 1985). A question arises whether in the normal organism the postexercise elevation of renal clearance of urea is caused by an increased level of glucocorticoids in blood. An affirmative answer might be deduced from the delayed response of urea washout after 10-h swimming, because in normal rats exercises over $8 \mathrm{~h}$ in duration did not cause an increased level of corticosterone in blood plasma at the end of exercise as the swimming of shorter duration did (Table 2). After 10-h swimming, the blood corticosterone concentration was not determined just after the end of the exercise. However, the blood samples, collected after a 6-h recovery period, indicated the existence of a postexercise increase in the blood corticosterone level. Obviously, the elevated urea clearance followed the postexercise augmentation of the blood glucocorticoid level after 10 -h swimming.

The obtained results suggest that the glucocorticoids play a role both in urea formation during exercise and in its elevated renal clearance after exercise.

\section{REFERENCES}

Bellamy, D. and Leonard, R. A. (1964) The effect of cortisol on the activity of glutamate-pyruvate transaminase and the formation of glycogen and urea in starved rats. Biochem. J., 93: 331-336

Buhl, H., Lorenz, R., Israel, S., Neumann, G., and Kuppardt, H. (1974) Komplexe Untersuchungen über die Wirkung einer erschöpfenden Extensivbelastung bei Männer mittleren Altern. II Mitt. Untersuchungen vershiedenes Stoffwechselgröße. Med. Sport, 14: $231-240$.

Buhl, H., Newmann, G., Berger, G., and Gottschalk, K. (1978) Der extreme Dauerleistung. Fallstudie eines 24-Studen bzw. 100-km-Laufes. Med. Sport, 18: 454-458.

Chailley-Bert, P., Plas, P., Henry, M. A., and Bugard, P. (1961) Les modifications metaboliques an cours d'effort prolonges chez le sportif. Rev. Pathol. Gen., 61: 143-157.

Vol. 39, No. 5, 1989 
Dohm, G. L., Kasperek, G. J., Tapscott, E. B., and Barakat, H. A. (1985a) Protein metabolism during endurance exercise. Fed. Proc., 44: 348-352.

Dohm, G. L., Israel, R. G., Breedlove, R. L., Williams, R. T., and Askew, E. W. (1985b) Biphasic changes in 3-methylhistidine excretion in humans after exercise. Am. J. Physiol., 248: 588-592.

Dohm, G. L., Williams, R. T., KaspereK, G. J., and RiJ, A. M. (1982) Increased excretion of urea and $\mathrm{N}^{t}$-methylhistidine by rats and humans after a bout of exercise. J. Appl. Physiol., 52: 27-33.

ENGEL, F. L. (1951) A consideration of the roles of the adrenal cortex and stress in the regulation of protein metabolism. Recent Prog. Horm. Res., 6: 277-313.

Goodman, M. N. and Ruderman, N. B. (1987) Influence of muscle use on amino acid metabolism. Exercise Sports Sci. Rev., 10: 1-26.

Haralambie, G. and Berg, A. (1976) Serum urea and amino nitrogen changes with exercise duration. Eur. J. Appl. Physiol., 36: 39-48.

INGLE, D. J. (1949) Some studies on the role of the adrenal cortex in organic metabolism. Ann. N. Y. Acad. Sci., 50: 576-595.

KASPEREK, G. J. and SNIDER, R. D. (1985) Increased protein degradation after eccentric exercise. Eur. J. Appl. Physiol., 54: 30-34.

Kórge, P., Viru, A., and Roosson, S. (1974) The effect of chronic physical overload on skeletal muscle metabolism and adrenocortical activity. Acta Physiol. Acad. Sci. Hung., 45: $41-51$.

Lemon, P. W. R. and Mullin, J. P. (1980) The effect of initial muscle glucogen levels on protein catabolism during exercise. J. Appl. Physiol., 48: 624-629.

Lemon, P. W. R. and Nagle, F. J. (1981) Effects of exercise on protein and amino and metabolism. Med. Sci. Sports Exercise, 13: 141-149.

Lenkova, R. I., Usik, S. V., and Yakovlev, N. N. (1973) Changes of urea content in blood and tissues during muscular activity in dependence on the adaptation of organism. Sechenov Physiol. J. U.S.S.R., 59: 1097-1101 (in Russian).

LORENZ, R. and Gerber, G. (1979) Harnstoff bei körperlichen Belastungen: Veränderung der Synthese, der Blutkonzentration und der Ausscheidung. Med. Sport, 19: 240-248.

Lowenstein, J. M. (1972) Ammonia production in muscle and other tissues. The purine nucleotide cycle. Physiol. Rev., 52: 382-414.

Millward, D. J., Davies, C. T. M., Halliday, D., Wolman, S. L., Mathews, D., and RENNIE, M. (1982) Effect of exercise on protein metabolism in humans as explored with stable isotopes. Fed. Proc., 41: 2686-2691.

Refsum, H. E. and Strömme, S. B. (1974) Urea and creatinine production and excretion in urine during and after prolonged heavy exercise. Scand. J. Clin. Lab. Invest., 33: 247-254.

RogozkIN, V. A. (1959) Nitrogen metabolism in muscular activity of various duration. Ukr. Biochem. J., 31: 489-494 (in Russian).

Rowell, L. B. (1974) Human cardiovascular adjustments to exercise and thermal stress. Physiol. Rev., 54: 75-159.

SCHimke, R. T. (1963) Studies on factors affecting the levels of urea cycle enzymes in rat liver. J. Biol. Chem., 238: 1012-1018.

Steward, C. P., Albert-Recht, F., and Osman, L. M. (1961) The simultaneous fluorometric microdetermination of cortisol and corticosterone in plasma. Clin. Chim. Acta, 6: 696-707.

VIRU, A. (1985) Hormones in Muscular Activity, CRC Press, Boca Raton, Vol. 1. 
VIRU, A. (1987) Mobilization of structural proteins during exercise. Sports Med., 4: 95-128.

Viru, A. A., VarriK, E. V., ÖöpIK, E. V., Smirnova, T. A., and Viru, M. A. (1985) Recovery process after prolonged muscular work. Byull. Eksperim. Biol. Med., 100: 555-556 (in Russian).

YaKovLEV, N. N. (1979) Ornithine metabolism and adaptation to augmented muscular activity. Sechenov Physiol. J. U.S.S.R., 65: 979-984.

Zerbes, H., KüHNE, K., and Götte, H.-C. (1983) Der Einfluss von körperlicher Belastung und Eiweißgehalt der Nahrung auf die Harnstoffproduction, -exkretion und -retention. Med. Sport, 23: 299-301. 